\title{
Organic matter release by cold water corals and its implication for fauna-microbe interaction
}

\author{
Christian Wild ${ }^{1, *}$, Christoph Mayr ${ }^{2}$, Laura Wehrmann ${ }^{1,3}$, Sandra Schöttner ${ }^{1,3}$, \\ Malik Naumann ${ }^{1}$, Friederike Hoffmann ${ }^{3}$, Hans Tore Rapp ${ }^{4}$ \\ ${ }^{1}$ Coral Reef Ecology Work Group (CORE), GeoBio-Center and Department of Earth \& Environmental Science, \\ Ludwig-Maximilians Universität, Richard Wagner Str. 10, 80333 Munich, Germany \\ ${ }^{2}$ GeoBio-Center and Department of Earth \& Environmental Science, Ludwig-Maximilians Universität, Richard Wagner Str. 10, \\ 80333 Munich, Germany \\ ${ }^{3}$ Max Planck Institute for Marine Microbiology, Celsiusstr. 1, 28359 Bremen, Germany \\ ${ }^{4}$ University of Bergen, Centre for Geobiology and Department of Biology, PO Box 7800, Bergen, Norway
}

\begin{abstract}
Particulate (POM) and dissolved organic matter (DOM) released by the cold water corals Lophelia pertusa (L.) and Madrepora oculata (L.) was collected, analysed and quantitatively compared to that released by warm water reef-building corals. Particulate nitrogen (PN) and particulate organic carbon (POC) release rates of $L$. pertusa were $0.14 \pm 0.07 \mathrm{mg} \mathrm{N} \mathrm{m}^{-2} \mathrm{~h}^{-1}$ and $1.43 \pm$ $1.22 \mathrm{mg} \mathrm{C} \mathrm{m}^{-2} \mathrm{~h}^{-1}$, respectively, which is in the lower range of POM release rates measured for warm water corals, while dissolved organic carbon (DOC) release was $47 \pm 19 \mathrm{mg} \mathrm{C} \mathrm{m}^{-2} \mathrm{~h}^{-1}$. The resulting high DOC:POC ratio indicates that most cold water coral-derived organic matter immediately dissolved in the water column. Cold water corals, similar to their warm water counterparts, produced large amounts of nitrogen-rich coral mucus with C:N ratios of 5 to 7 for Lophelia- and 7 to 9 for Madrepora-derived mucus. A 7 -fold increase in the oxygen consumption rates in cold water coral mucus-amended seawater containing the natural microbial assemblage indicates that this organic matter provided an attractive food source for pelagic microbes. In situ investigations at Røst Reef, Norway, showed that microbial activity in the seawater closest to the reef was 10 times higher than in the overlying water column. This suggests that cold water corals can stimulate microbial activity in the direct reef vicinity by the release of easily degradable and nutrient-rich organic matter, which may thereby function as a vector for carbon and nutrient cycling via the microbial loop in cold water coral reef systems.
\end{abstract}

KEY WORDS: Coral reefs $\cdot$ Cold water corals $\cdot$ Lophelia pertusa $\cdot$ Madrepora oculata $\cdot$ Organic matter release $\cdot$ Microbial ecology $\cdot$ Fauna-microbe interaction

\section{INTRODUCTION}

Although only recently discovered and still far from completely explored, cold water coral reefs are highly endangered by direct anthropogenic threats such as bottom trawling, hydrocarbon drilling and seabed mining, and also by climate change consequences such as ocean acidification (Roberts et al. 2006). Taxonomic surveys in various cold water coral reefs showed that these ecosystems are hotspots for biodiversity, providing habitat for more than 1300 benthic species (Jensen \& Frederiksen 1992, Mortensen et al. 1995, Rogers 1999, Freiwald et al. 2004, Roberts et al. 2006). However, ecological studies focusing on interactions between corals and cold water coral reef-associated organisms, in particular on the role of reef-associated planktonic microbial communities, have not been conducted to our knowledge, although such investigations may provide fundamental insights into the functioning of the ecosystem in cold water coral reefs. This pilot study aims to contribute in this context.

It is known from warm water reefs that hard and soft corals release organic matter, comprising spawning 
products and mucus (e.g. Harrison et al. 1984, Crossland 1987), in dissolved (Ferrier-Pages et al. 1998) or particulate form into their surroundings. The release of organic matter by corals makes an important contribution to the ecological functioning of tropical coral reefs by controlling key processes such as the transport of organic matter. This, in turn, may influence planktonic and benthic metabolism as well as the associated recycling of essential elements. Mass release of eggs and sperm during the annual coral spawning event can have extensive biogeochemical consequences (Wild et al. 2004c, 2008, Eyre et al. 2008, Glud et al. 2008). Furthermore, mucus continuously released by tropical corals can act as an energy carrier and particle trap (Wild et al. 2004a) and consequently initiates element cycling and interaction between fauna and microorganisms in tropical reef ecosystems. Within this context, coral-derived mucus can strongly influence planktonic microbial metabolism (Ferrier-Pages et al. 2000), microbial abundance (Wild et al. 2004b) and microbial community composition (Allers et al. 2008).

Cold water coral reefs exist in different environmental settings compared to their warm water counterparts (Freiwald et al. 2004, Roberts et al. 2006). Visual observations showed that cold water corals are also, in principle, able to release large amounts of organic matter as mucus into the surrounding water, at least under massive stress conditions (Reitner 2005). However, the need for nutrient conservation by possible trapping of suspended particles via coral-derived organic matter as suggested by Wild et al. (2004a) seems to be less important in these ecosystems, which are influenced by high current velocities and often nutrient-rich waters (Roberts et al. 2006). The ecological function of organic matter release by cold water corals is entirely unknown. The present study, therefore, provides the first data on the quantity of dissolved (DOM) and particulate organic matter (POM) released by the cosmopolitan cold water coral Lophelia pertusa (L.). Furthermore, pilot investigations at Røst Reef, Norway, the largest cold water coral reef system discovered to date (Freiwald et al. 2004), are presented. These investigations target the microbial degradability of coralderived organic matter and its possible implications for cold water coral reef-associated microbial metabolism and fauna-microbe interactions in the reef ecosystem.

\section{MATERIALS AND METHODS}

Study site. The different investigations described in this study were conducted at the aquarium facilities of the University of Bergen, Norway, in October 2006 and during the RV 'Polarstern' cruise ARK-XXII/1a to the Mid-Norwegian continental shelf in June 2007.
Quantification of organic matter release rates. Release rates of DOM as well as POM were quantified using the beaker incubation technique initially described by Herndl \& Velimirov (1986). Prior to the experiments, a large colony (diameter: ca. $40 \mathrm{~cm}$ ) of the cold water coral Lophelia pertusa, collected from Langenuen, a fjord area south of Bergen (position: 60 $25^{\circ} \mathrm{N}, 06^{\circ} 31^{\prime} \mathrm{E}$; water depth: ca. $120 \mathrm{~m}$ ), was kept in a flow-through aquarium with continuous inflow of in situ seawater pumped from a water depth of ca. $100 \mathrm{~m}$ for more than 6 mo. This resulted in stable salinities (32.5 to 33.8) and a constant water temperature of ca. $11^{\circ} \mathrm{C}$ over the whole maintenance period as monitored from regular measurements using refractometer and thermometer. The colony was broken into fragments (length: 2 to $9 \mathrm{~cm}$ ) using a wire cutter. These fragments were left in the maintenance aquarium for at least $3 \mathrm{~d}$ to recover prior to the experiment. For the experiment, 5 fragments were separately transferred (without air exposure) into $1 \mathrm{l}$ glass beakers filled with 700 to $800 \mathrm{ml}$ of untreated seawater from the aquarium. Three additional glass beakers, which served as controls, were filled with seawater from the aquarium only. All 8 beakers were kept in a flow-through aquarium in order to maintain an in situ temperature of $11^{\circ} \mathrm{C}$ during the entire $4 \mathrm{~h}$ dark incubation. During the beaker incubation it was observed that between 25 and $40 \%$ of the fragment polyps were protruded, which was well in the range of the mother colony and thus indicated an advanced recovery of the fragments, i.e. that duration of the healing period was sufficient.

Following incubation, coral fragments were removed from the beakers, the incubation water in the beakers was homogenized by gentle stirring for at least $30 \mathrm{~s}$, and sub-samples were taken as follows. Samples for measurement of dissolved organic carbon (DOC) were prepared by filtering $(0.2 \mu \mathrm{m}$ Millex Nylon membrane filters) $2 \mathrm{ml}$ incubation water aliquots into precombusted $3 \mathrm{ml}$ brown glass vials (prior to this, another $2 \mathrm{ml}$ aliquot of each incubation volume was prefiltered and discarded in order to clean the respective filter). Samples were immediately frozen at $-20^{\circ} \mathrm{C}$ and kept frozen until analysis. Samples for measurement of particulate organic C (POC) and particulate N (PN) concentrations and their stable isotope signatures were prepared by filtering $200 \mathrm{ml}$ incubation water aliquots onto pre-combusted GF/F filters (Whatman, $25 \mathrm{~mm}$ in diameter; combusted for 4 to $6 \mathrm{~h}$ at $500^{\circ} \mathrm{C}$ ). The filters were dried for at least $48 \mathrm{~h}$ at $40^{\circ} \mathrm{C}$ and kept dry until analysis as described below. Organic matter release rates were related to the coral surface area, which was assessed by application of a geometric approximation method in combination with a specific SAI (surface area approximation index) for Lophelia pertusa, derived from comparative analysis with a 
computer tomography based surface area measurement technique (M. Naumann et al. unpubl.). Briefly, fragments were notionally divided into several branch sections with simple cylinder shape. Radius and height of each branch were assessed using a conventional caliper (accuracy: $\pm 0.05 \mathrm{~mm}$ ), measuring the diameter of the branch base and the height from branch base to tip. Measured parameters were applied in the calculation of cylinder superficies surface area and cylinder cover area using conventional surface area formulas. Cylinder surface areas from all branches were added to gain the total fragment surface area, which was finally multiplied by the above-mentioned SAI to improve accuracy.

Mucus composition and microbial degradation. During the RV 'Polarstern' cruise, several large colonies (diameter $>30 \mathrm{~cm}$ ) of the cold water corals Lophelia pertusa (L.) and Madrepora oculata (L.) were collected by the manned submersible JAGO (IFM-Geomar, Kiel) during 3 dives at Røst Reef $\left(67^{\circ} 31.22^{\prime} \mathrm{N}, 9^{\circ} 28.43^{\prime} \mathrm{E}\right)$, Norway, from water depths of 310 to $380 \mathrm{~m}$. These coral colonies were immediately transferred into $300 \mathrm{l}$ glass aquaria filled with fresh bottom water and kept at $6^{\circ} \mathrm{C}$ in a cooling chamber on board the research vessel for less than $3 \mathrm{~d}$ before sample collection. Mucus was collected from 3 to 4 fragments of each of the following cold water coral colour morphotypes: (1) white L. pertusa, (2) pink L. pertusa, (3) white M. oculata and (4) orange $M$. oculata (see Fig. 1), by exposing the corals to air for $5 \mathrm{~min}$ and collecting the produced gel-like mucus in a clean glass dish. Depending on produced volume, between 2 and $20 \mathrm{ml}$ of mucus from each coral fragment were filtered onto pre-combusted GF/F filters. In addition, bottom water samples from between 4 and $10 \mathrm{~m}$ height above Røst Reef were collected on 3 occasions (June 8, 9, 12, 2007; using CTD-attached 201 Niskin bottles) and filtered in volumes of 250 or $500 \mathrm{ml}$ onto precombusted GF/F filters in triplicate for each sampling occasion. All filters were dried at $40^{\circ} \mathrm{C}$ for at least $48 \mathrm{~h}$, and their POC as well as PN contents quantified as described below.

In order to measure microbial degradation of coral mucus, aliquots of freshly collected mucus from the orange Madrepora oculata colonies in a dilution of 1:10 (mucus:bottom water) and pure bottom water as reference were incubated for up to $200 \mathrm{~h}$ in $30 \mathrm{ml}$ Winkler glass bottles under dark conditions at in situ tempera- ture $\left(5^{\circ} \mathrm{C}\right)$. The $\mathrm{O}_{2}$ concentrations in both treatments were measured in parallel time series using the Winkler titration method, with each sampling point representing an individual Winkler bottle. The $\mathrm{O}_{2}$ consumption rates were calculated in $\mu \mathrm{M} \mathrm{l}^{-1}$ using linear regression with at least 4 data points. Microbial $\mathrm{C}$ degradation was calculated by relating the oxygen consumption rates to the respective $\mathrm{C}$ content of each organic matter source (measured as described above in replicates of $n=4$ ) assuming that $1 \mathrm{~mol}$ of organic $\mathrm{C}$ is oxidized by $1 \mathrm{~mol}$ of $\mathrm{O}_{2}$.

Planktonic microbial oxygen demand above Røst Reef. A CTD-attached water sampling device was used from the research vessel in order to collect water samples from various water depths above a small reef valley (exact coordinates: 67² $31.217^{\prime} \mathrm{N}, 9^{\circ} 28.430^{\prime} \mathrm{E}$ ) in $328 \mathrm{~m}$ water depth within Røst Reef. Water samples from 4, 11, 16, 21, 26, 32, 47 and $177 \mathrm{~m}$ above Røst Reef were retrieved using 201 Niskin bottles. Aliquot water samples from each water depth were filled into 2 ca. $120 \mathrm{ml}$ Winkler glass bottles for determination of oxygen concentration and planktonic microbial oxygen demand. One of the bottles filled with water from each depth was used for oxygen concentration determination using Winkler titration, and the other one was incubated for $134 \mathrm{~h}$ in the dark and at in situ temperature in a cold room on board. After this period, $\mathrm{O}_{2}$ concentration of the incubated water samples was measured using Winkler titration (Winkler 1888) and subtracted from the start values in order to calculate 
planktonic microbial oxygen demand. Replicate measurements $(\mathrm{n}=4)$ of $\mathrm{O}_{2}$ consumption rates in bottles filled with the same seawater were within $1.2 \%$.

In addition, $500 \mathrm{ml}$ aliquots ( $\mathrm{n}=1$ to 3 for each depth) from the water sampled in vertical resolution were filtered onto pre-combusted ( 4 to $6 \mathrm{~h}$ at $500^{\circ} \mathrm{C}$ ) Whatman $\mathrm{GF} / \mathrm{F}$ filters. The filters were dried for at least $48 \mathrm{~h}$ at $40^{\circ} \mathrm{C}$ and kept dry until POM analyses as described below.

Stable isotope and elemental analyses. DOC concentrations were quantified by high-temperature catalytic oxidation (HTCO) using a Rosemount Dohrmann DC190 TOC (total organic carbon) analyzer. POC and PN concentration measurements and respective stable isotope analyses were performed with a Carlo Erba NC 2500 elemental analyzer, coupled with a THERMO/ Finnigan Conflo II-interface to a THERMO/Finnigan MAT Delta plus isotope ratio mass spectrometer. $\mathrm{C}$ and $\mathrm{N}$ elemental concentration measurements were calculated from certified elemental standards (atropine, cyclohexanone-2,4-dinitrophenylhydrazone; Thermo Quest) analysed within each batch and typically showed standard deviations $<3 \%$. Stable isotope ratios are given in the conventional delta notation $\left(\delta^{13} \mathrm{C}, \delta^{15} \mathrm{~N}\right)$ relative to Vienna PeeDee Belemnite (VPDB) standard (Craig 1957, Coplen 1995) and atmospheric nitrogen (Mariotti 1983), respectively. Standard deviations for repeated stable isotope measurements of lab standard (Peptone) with a broad range of initial weights were better than $0.15 \%$ for nitrogen and carbon, respectively. Within each run, linearity was checked with isotope standards of different initial weights and data outside the linearity range were discarded or-if feasible-linearity corrected. Filters were not treated with $\mathrm{HCl}$ in order to prevent disturbance or falsification of the $\delta^{15} \mathrm{~N}$ signatures. Inorganic carbon was not present in the samples as evidenced from test measurements of the mucus and water samples.

\section{RESULTS}

\section{Organic matter release by cold water corals}

The fragments of Lophelia pertusa released all investigated kinds of organic matter (POC, PN and DOC) in significant quantities (Table 1). The mean ratio between DOC and POC was greater than 30, which indicates that most of the coral-derived organic carbon entered the DOM pool in the water column close to cold water corals. POC and PN release rates of L. pertusa $\left(1.43 \pm 1.22\right.$ and $0.14 \pm 0.07 \mathrm{mg} \mathrm{m}^{-2} \mathrm{~d}^{-1}$, respectively) were in the lower range of rates reported from various warm water corals (POC: 0.8 to 88.8 and PN 0.04 to $1.30 \mathrm{mg} \mathrm{m}^{-2} \mathrm{~d}^{-1}$ ), whereas L. pertusa DOC release was always positive in contrast to DOC release rates reported for warm water corals, which were highly variable and often negative, indicating DOC uptake by the corals (Table 1).

\section{Mucus composition and microbial degradation}

Cold water coral mucus collected from the 4 different investigated colour morphotypes showed clear compositional differences (Fig. 2a). However, all coral

Table 1. Organic matter release rates of the investigated cold water coral in comparison with release rates reported for warm water corals. PN: particulate nitrogen: POC: particulate organic carbon; DOC: dissolved organic carbon. Values given as mean \pm SD where applicable

\begin{tabular}{|c|c|c|c|c|c|c|}
\hline Study site & Species & $\begin{array}{l}\text { PN release } \\
\left(\mathrm{mg} \mathrm{m}^{-2} \mathrm{~h}^{-1}\right)\end{array}$ & $\begin{array}{l}\text { POC release } \\
\left(\mathrm{mg} \mathrm{m}^{-2} \mathrm{~h}^{-1}\right)\end{array}$ & $\begin{array}{l}\text { DOC release } \\
\left(\mathrm{mg} \mathrm{m}^{-2} \mathrm{~h}^{-1}\right)\end{array}$ & Method & Source \\
\hline Bergen, Norway & Lophelia pertusa & $0.14 \pm 0.07$ & $1.43 \pm 1.22$ & $47 \pm 19$ & $\begin{array}{c}\text { Beaker } \\
\text { incubation }\end{array}$ & Present study \\
\hline Aqaba, Jordan & Various species & 0.04 to 0.48 & 0.8 to 6.9 & -351 to 75 & $\begin{array}{c}\text { Beaker } \\
\text { incubation }\end{array}$ & $\begin{array}{l}\text { M. Naumann et al. } \\
\text { (unpubl. data) }\end{array}$ \\
\hline $\begin{array}{l}\text { Ishigaki Island, } \\
\text { Japan }\end{array}$ & Porites cylindrica & Not measured & 70.8 & 40.8 & $\begin{array}{l}\text { Container } \\
\text { incubation }\end{array}$ & Tanaka et al. (2008) \\
\hline $\begin{array}{l}\text { Ishigaki Island, } \\
\text { Japan }\end{array}$ & Acropora pulchra & Not measured & 88.8 & 45.6 & $\begin{array}{l}\text { Container } \\
\text { incubation }\end{array}$ & Tanaka et al. (2008) \\
\hline $\begin{array}{l}\text { Heron Island, } \\
\text { Australia }\end{array}$ & Acropora millepora & $1.30 \pm 0.80$ & $10.0 \pm 5.0$ & Not measured & $\begin{array}{c}\text { Beaker } \\
\text { incubation }\end{array}$ & Wild et al. (2005) \\
\hline Eilat, Israel & Acropora variabilis & Not measured & 1.4 to 4.2 & Not measured & $\begin{array}{l}\text { Chamber } \\
\text { incubation }\end{array}$ & Crossland (1987) \\
\hline Eilat, Israel & Stylophora pistillata & Not measured & 2.7 to 4.0 & Not measured & $\begin{array}{l}\text { Chamber } \\
\text { incubation }\end{array}$ & Crossland (1987) \\
\hline $\begin{array}{l}\text { Bight of Piran, } \\
\text { Croatia }\end{array}$ & Cladocora cespitosa & Not measured & 6.0 & Not measured & $\begin{array}{c}\text { Beaker } \\
\text { incubation }\end{array}$ & $\begin{array}{c}\text { Herndl \& Velimirov } \\
\text { (1986) }\end{array}$ \\
\hline
\end{tabular}


mucus samples were significantly enriched in $\mathrm{N}$ compared to POM suspended in the water close to the cold water coral reef (2-sided $U$-test after Wilcoxon, Mann and Whitney, $\alpha=0.05$ ). Mucus collected from Lophelia pertusa showed significantly lower C:N values (1-sided $U$-test after Wilcoxon, Mann and Whitney, $\alpha=0.001)$ compared to all mucus samples collected from Madrepora oculata, with minimum values of less than 6 for the white L. pertusa, which is even lower than the Redfield ratio (Fig. 2a). Values of $\delta^{13} \mathrm{C}$ for all mucus samples from the $L$. pertusa fragments were significantly heavier compared to the $\delta^{13} \mathrm{C}$ values of $M$. oculata mucus samples and POM suspended in bottom waters $(1$-sided $U$-test after Wilcoxon, Mann and Whitney, $\alpha<0.05$ ), whereas no significant differences occurred between $M$. oculata
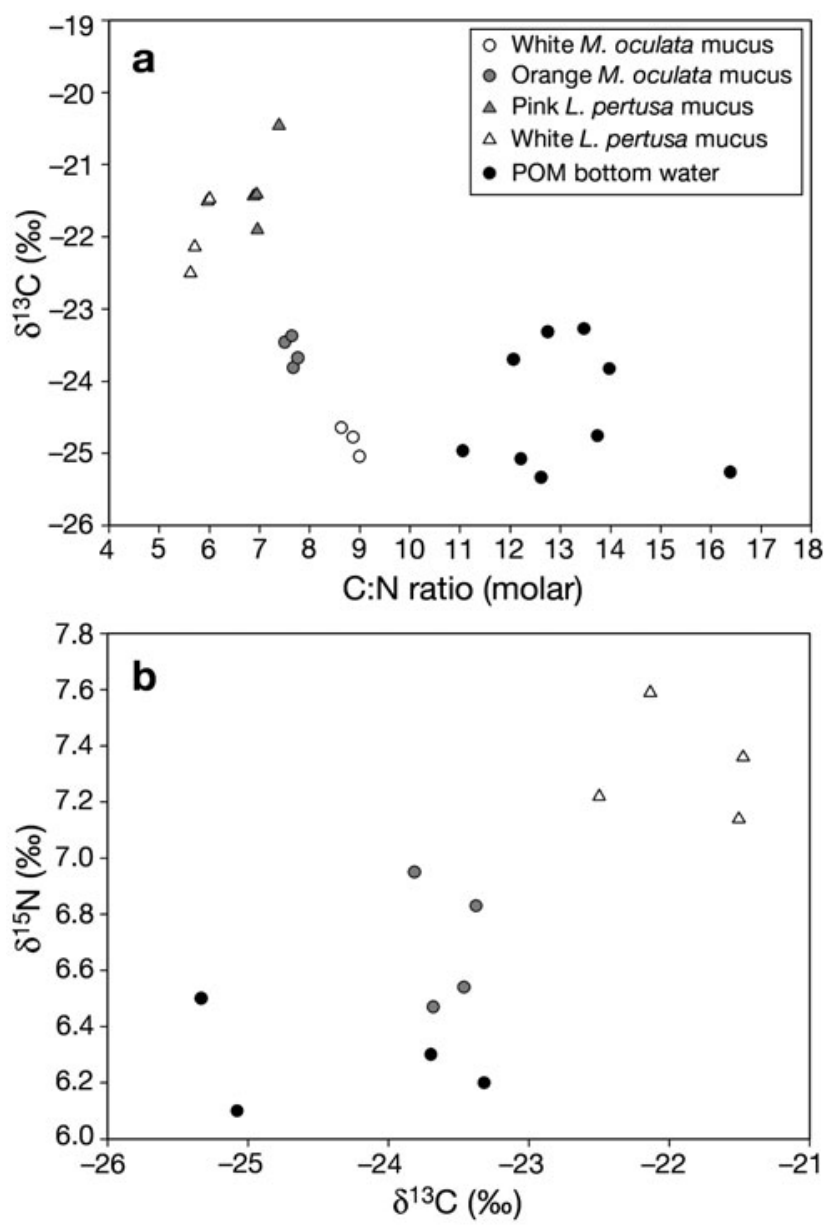

Fig. 2. Lophelia pertusa and Madrepora oculata. (a) C:N ratios versus carbon stable isotope signatures, and (b) carbon versus nitrogen stable isotope signatures of mucus released by different colour morphotypes of the cold water corals in comparison with particulate organic matter (POM) suspended in bottom water samples close (less than $40 \mathrm{~m}$ distance) to Røst Reef, Norway mucus and POM. Coral mucus $\delta^{15} \mathrm{~N}$ values showed similar trends with samples from white $L$. pertusa fragments, exhibiting significantly $(\alpha=0.05)$ heavier $\mathrm{N}$ isotope signatures (increase of ca. $1 \%$ ) compared to both orange $M$. oculata mucus samples and bottom water POM, whereas the latter 2 were not significantly different (Fig. 2b).

The mucus degradation experiment revealed that mucus released by cold water corals serves as an attractive substrate for reef-associated planktonic microorganisms. Oxygen was consumed 7 times faster in those incubation bottles filled with 1:10 diluted coral mucus compared to those only filled with seawater (Fig. 3). This corresponds to a microbial organic $\mathrm{C}$ degradation of ca. $8 \%$ of the added coral mucus per day assuming that $1 \mathrm{~mol}$ organic $\mathrm{C}$ is oxidized by $1 \mathrm{~mol}$ of $\mathrm{O}_{2}$.

\section{Microbial activity in the water column above Røst Reef}

Microbial $\mathrm{O}_{2}$ consumption rates were less than $10 \mu \mathrm{g}$ $\mathrm{l}^{-1} \mathrm{~d}^{-1}$ in all samples, except the sample from the station closest to the reef, where values of more than $60 \mathrm{\mu g} \mathrm{l}^{-1} \mathrm{~d}^{-1}$ were recorded (Fig. 4). These maximum values were limited to the water column directly (less than $4 \mathrm{~m}$ distance) above the reef. By $10 \mathrm{~m}$ distance above the coral reef, $\mathrm{O}_{2}$ consumption rates dropped down to the abovementioned low values (Fig. 4) In the remaining water column, oxygen consumption rates varied between 0 and $10 \mu \mathrm{g} \mathrm{l}^{-1} \mathrm{~d}^{-1}$, reflecting the pattern of the POM concentrations, which varied between 40 and $60 \mu \mathrm{g} \mathrm{l}^{-1}$.

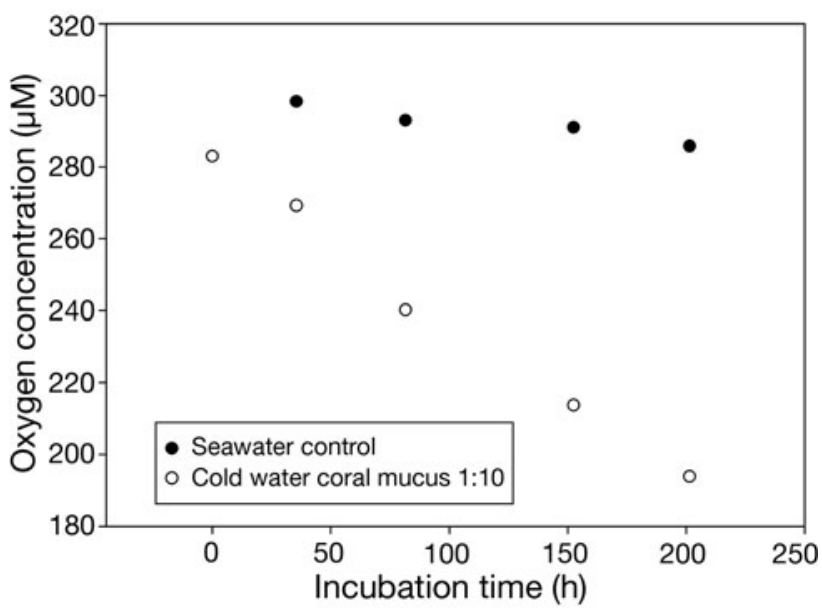

Fig. 3. Madrepora oculata. Oxygen $\left(\mathrm{O}_{2}\right)$ concentrations in glass incubation bottles filled with bottom water collected at Røst Reef and cold water coral mucus, 1:10 diluted with the bottom water 


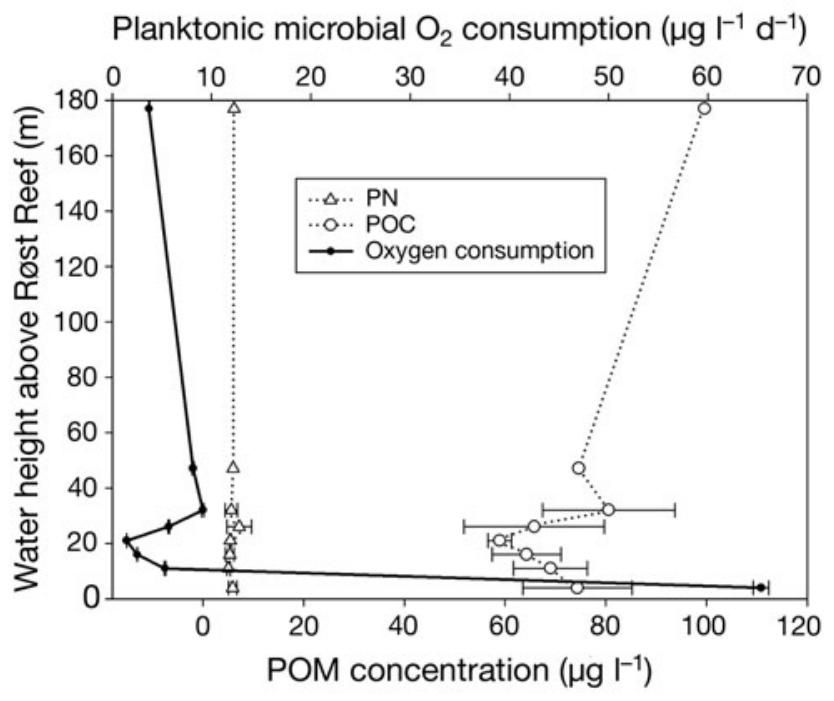

Fig. 4. Particulate organic matter (POM) concentrations and microbial $\mathrm{O}_{2}$ consumption measured in a vertical profile in the water column above Røst Reef. PN: particulate nitrogen; POC: particulate organic carbon. Values are means $\pm \mathrm{SD}$ ( $\mathrm{n}=1$ to 3 ). Error bars for microbial $\mathrm{O}_{2}$ consumption indicate the methodological error of $1.2 \%(n=4)$

\section{DISCUSSION}

\section{Cold water coral-derived organic matter: quantity and quality}

The results of this study show that cold water corals, similar to warm water corals, release organic matter in dissolved and particulate form. The investigated cold water coral Lophelia pertusa released clearly more DOC than POC, which contrasts with the recent study of Tanaka et al. (2008), who found higher POC than DOC release by the warm water corals Acropora pulchra and Porites cylindrica (Table 1). In general, POC release by the cold water coral tended to be lower, and DOC release rates tended to be higher than rates reported for warm water corals (see Table 1 and references therein).

It is known from warm water corals that POM release may function as a protection mechanism against bio-fouling (Ducklow \& Mitchell 1979), high particle loads in the water column (Rublee et al. 1980) and sedimentation (Schuhmacher 1977). While bio-fouling does seem to affect cold water corals as well (Freiwald et al. 2004, Hall-Spencer et al. 2007), the Norwegian cold water coral reefs apparently often experience low turbidity and sedimentation rates (Mortensen et al. 2001). Release of POM may thus have a general function against bio-fouling for all corals independent of the surrounding conditions including light and temperature. However, the question arises as to how azooxanthellate cold water corals are able to invest similar amounts of energy and nutrients in the production of released organic matter compared to zooxanthellate warm water corals, which derive large proportions of their energy demand from their endosymbiotic algae (Muscatine et al. 1981). Up to half of the carbon assimilated by the endosymbiotic algae can be released as mucus by warm water corals (Davies 1984, Crossland et al. 1987), and chemical analyses showed that carbohydrate mucus components such as arabinose are directly transferred from the algae to the coral host (Meikle et al. 1988).

The low C:N ratios measured for mucus from different cold water corals indicate that $\mathrm{N}$-containing components like glycoprotein, as found in warm water coral-derived organic matter (Meikle et al. 1987), are main components of this organic material. These components may be responsible for the high $\mathrm{N}$-content, which was close to or even slightly below the Redfield ratio, thereby valorising cold water coral mucus to an attractive and easily accessible food source for heterotrophic microorganisms.

Release of DOC could be measured for all investigated cold water corals, whereas quantification experiments for DOC release of warm water corals often showed net uptake of DOC through the corals (Ferrier 1991, Ferrier-Pages et al. 1998, M. Naumann et al. unpubl. data). Warm water corals thus seem to behave more conservatively with DOC than cold water corals, probably due to the condition of warm water coral reefs which are often more oligotrophic, which necessitates the retention of DOC-associated essential nutrients such as nitrogen and phosphorus. In cold water coral reefs, where more planktonic food is usually available for the corals (e.g. Freiwald et al. 2004), it may be energetically more favourable to release DOC into the surrounding water.

Carbon stable isotope signatures show clear differences between the mucus released by the 2 investigated cold water corals Lophelia pertusa and Madrepora oculata. Such differences were also observed for the nitrogen stable isotope signatures of the mucus from the white $L$. pertusa and orange M. oculata morphotypes. Assuming that mucus reflects tissue signatures (which is supported by very similar C stable isotope signatures of $-22.0 \pm 0.2 \%$ for L. pertusa tissue samples from the fragments used in Bergen compared to $-21.9 \pm 0.5 \%$ o for coral mucus samples from Røst Reef), these species-specific differences in carbon and nitrogen stable isotope signatures may point towards species-specific metabolic differences as suggested by Weisz et al. (2007) for sponges, or towards different feeding strategies, 
which is supported by higher $\delta^{15} \mathrm{~N}$ and monounsaturated fatty acid contents found in the tissue of L. pertusa compared to M. oculata (Kiriakoulakis et al. 2005). Carbon stable isotope signatures of all POM samples from the water column close to (Fig. 1) or above Røst Reef (Fig. 3) were in the range of values for mucus samples from $M$. oculata, but always more negative compared to the respective values for $L$. pertusa. The $\delta^{15} \mathrm{~N}$ values of $L$. pertusa mucus were enriched by $1 \%$ compared to POM, while those of $M$. oculata mucus were in the range of POM values. This may indicate that POM cannot act as the only food source for either $M$. oculata or L. pertusa, which would result in a $\sim 3 \%$ increase of $\delta^{15} \mathrm{~N}$ per trophic level (Peterson \& Fry 1987). The low $\delta^{15} \mathrm{~N}$ values in both coral species may be explained by substantial inputs of $\mathrm{N}$ from autochthonous microbial sources (Weisz et al. 2007). However, seasonal variations of the $\delta^{15} \mathrm{~N}$ signature of POM (Duineveld et al. 2004) as well as direct feeding on zooplankton, as observed by Rapp \& Sneli (1999) for L. pertusa, may also contribute to the stable isotope composition of cold water corals. Further investigation is needed to explain the observed differences in the isotopic signature of L. pertusa and M. oculata, and to identify the main food sources of these species.

\section{Organic matter degradability and fauna-microbe interaction}

The enhanced respiration rates in mucus-enriched seawater showed that mucus released by cold water corals is an attractive substrate for planktonic microorganisms living in the water column. Thus, mucus can act as a vector for energy from the corals to these microbes. Approximately $8 \%$ of the added coral mucus was mineralized by planktonic microbes per day at an in situ temperature of $6^{\circ} \mathrm{C}$. It is difficult to compare these degradation rates with those of warm water coral mucus because of the apparent large temperature differences. However, assuming that after Van't Hoff's rule a $10^{\circ} \mathrm{C}$ temperature increase doubles the velocity of biological processes (Harvey 1916), this would result in a temperature-corrected microbial organic $\mathrm{C}$ degradation rate of $1.4 \% \mathrm{~h}^{-1}$ at $26^{\circ} \mathrm{C}$ compared to a rate of $7.0 \% \mathrm{~h}^{-1}$ measured for warm water coral mucus at identical temperature (Wild et al. 2004a,b). This also illustrates the similarity of both coral-derived substrates with respect to attractiveness for microbial degradation, although cold water coral mucus seems to exhibit a more refractory character.

Intense fauna-microbe interaction via coral mucus is apparently established in both warm and cold water coral reef ecosystems. This may have strong effects on microbial diversity and activity as well as concomitant recycling of organic matter and ecosystem productivity. The present study shows that there may be a stimulation of the planktonic microbial activity in the water column directly above a proliferating reef, likely due to organic matter release by reef corals. The vertical measurements presented in Fig. 4 indicate that POM, which may fuel planktonic respiration in large parts of the water column, could not cause this stimulation of respiration rates directly above the reef. More likely, increased DOC concentrations in the direct vicinity of the reef, with coral-released mucus as a possible DOC source, were responsible for the observed stimulation of activity. This is supported by the high DOC:POC ratio of coral-derived organic matter as obtained in the laboratory study, and by the attractiveness of mucus to heterotrophic microbes, which is shown by its high $\mathrm{N}$-content and by the results of the bottle incubations presented in this study. A study by S. Schöttner et al. (unpubl. data) also confirms a potential parallel effect of coralderived organic matter on microbial diversity by showing that mucus from Lophelia pertusa supports a specifically associated microbial community, which is significantly different compared to that in the surrounding seawater and reef sediments.

Furthermore, the study of L. Wehrmann et al. (unpubl. data), who investigated biogeochemical processes in sediments associated to the Norwegian cold water coral reefs, including Røst Reef, indicates that a large amount of the suspended organic carbon may already be turned over in the water column or the reef framework while microbial mediated carbon turnover rates including organoclastic sulphate reduction rates (SRR) in the subsurface sediments underlying these

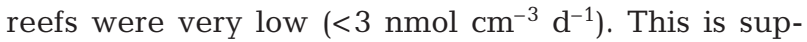
ported by the recent study of van Duyl et al. (2008), who showed that sponge-microbe consortia, which are often associated with cold water coral reefs (Roberts et al. 2003, 2006, van Soest et al. 2007), can incorporate DOC at high rates. It remains speculation and a potential target issue of future studies as to whether DOM excretion by cold water corals and subsequent stimulation of microbial growth near the reef may help the corals and associated organisms to prey on microbes.

Unlike warm water reefs, which mostly rely on sunlight as a direct energy source, cold water coral reefs entirely rely on the export of organic matter from primary production in surface waters to the seafloor (Duineveld et al. 2004, Thiem et al. 2006). The findings of the present study suggest that organic matter not only functions as a pre-requisite for cold water coral reef occurrence, but also acts as a trophic link for intense interactions between the different reef organisms. 
Acknowledgements. We thank the staff of Bergen University and the Industrial Laboratories (in particular Karin Engelstad) as well as the captain and crew of the RV 'Polarstern' for great help. Antje Boetius (MPI Bremen) is acknowledged for facilitating our participation in the 'Polarstern' cruise. Andreas Haas (CORE, Munich) and Matthias Birkicht (ZMT, Bremen) are acknowledged for assistance with the DOC analyses, and Chris Williamson (CORE, Munich) for correcting the language as a native speaker. We also thank the Contributing Editor Peter J. Edmunds and 3 anonymous reviewers for helping to improve our manuscript. This research was funded by German Research Foundation (DFG) grants Wi 2677/2-1 and Wi 2677/3-1 to C.W.

\section{LITERATURE CITED}

Allers E, Niesner C, Wild C, Pernthaler J (2008) Microbes enriched in seawater after the addition of coral mucus. Appl Environ Microbiol 74:3274-3278

Coplen TB (1995) Reporting of stable hydrogen, carbon, and oxygen isotopic abundances. Geothermics 24:707-712

> Craig H (1957) Isotopic standards for carbon and oxygen and correction factors for mass-spectrometric analysis of carbon dioxide. Geochim Cosmochim Acta 12:133-149

Crossland C (1987) In situ release of mucus and DOC-lipid from the corals Acropora variabilis and Stylophora pistillata in different light regimes. Coral Reefs 6:35-42

Davies PS (1984) The role of zooxanthellae in the nutritional energy requirements of Pocillopora eydouxi. Coral Reefs 2(4):181-186

Ducklow H, Mitchell R (1979) Bacterial populations and adaptations in the mucus layers on living corals. Limnol Oceanogr 24:715-725

> Duineveld GCA, Lavaleye MSS, Berghuis EM (2004) Particle flux and food supply to a seamount cold-water coral community (Galicia Bank, NW Spain). Mar Ecol Prog Ser 277: $13-23$

Eyre BD, Glud RN, Patten N (2008) Mass coral spawning: a natural large-scale nutrient addition experiment. Limnol Oceanogr 53:997-1013

Ferrier MD (1991) Net uptake of dissolved free amino acids by 4 scleractinian corals. Coral Reefs 10:183-187

Ferrier-Pages C, Gattuso JP, Cauwet G, Jaubert J, Allemand $\mathrm{D}$ (1998) Release of dissolved organic carbon and nitrogen by the zooxanthellate coral Galaxea fascicularis. Mar Ecol Prog Ser 172:265-274

> Ferrier-Pages C, Leclercq N, Jaubert J, Pelegri SP (2000) Enhancement of pico- and nanoplankton growth by coral exudates. Aquat Microb Ecol 21:203-209

Freiwald A, Fossa JH, Grehan A, Koslow T, Roberts JM (2004) Cold-water coral reefs, Vol 1. UNEP-WCMC, Cambridge

Glud RN, Eyre BD, Patten N (2008) Biogeochemical consequences to mass coral spawning at the Great Barrier Reef. Limnol Oceanogr 53:1014-1024

Hall-Spencer JM, Pike C, Munn CB (2007) Diseases affect cold-water corals too: Eunicella verrucosa (Cnidaria: Gorgonacea) necrosis in SW England. Dis Aquat Org 76: 87-97

Harrison PL, Babcock RC, Bull GD, Oliver JK, Wallace CC, Willis BL (1984) Mass spawning in tropical reef corals. Science 223(4641):1186-1189

Harvey EN (1916) Temperatur und Lebensvorgänge. Science 43:466-467

Herndl GJ, Velimirov B (1986) Microheterotrophic utilization of mucus released by the Mediterranean coral Cladocora cespitosa. Mar Biol 90:363-369
Jensen A, Frederiksen R (1992) The fauna associated with the bank-forming deep-water coral Lophelia pertusa (Scleractinaria) on the Faroe Shelf. Sarsia 77:53-69

Kiriakoulakis K, Fisher E, Wolff GA, Freiwald A, Grehan A, Roberts JM (2005) Lipids and nitrogen isotopes of two deep-water corals from the North-East Atlantic: initial results and implications for their nutrition. In: Freiwald A, Roberts JM (eds) Cold water corals and ecosystems. Springer, Berlin, p 715-729

Mariotti A (1983) Atmospheric nitrogen is a reliable standard for natural ${ }^{15} \mathrm{~N}$ abundance measurements. Nature 303: $685-687$

> Meikle P, Richards GN, Yellowlees D (1987) Structural determination of the oligosaccharide side-chains from a glycoprotein isolated from the mucus of the coral Acropora formosa. J Biol Chem 262:16941-16947

Meikle P, Richards GN, Yellowlees D (1988) Structural investigations on the mucus from six species of coral. Mar Biol 99: 187-193

Mortensen PB, Hovland M, Brattegard T, Farestveit R (1995) Deep-water bioherms of the scleractinian coral Lophelia pertusa (L) at $64^{\circ} \mathrm{N}$ on the Norwegian Shelf-structure and associated megafauna. Sarsia 80:145-158

Mortensen PB, Hovland MT, Fossa JH, Furevik DM (2001) Distribution, abundance and size of Lophelia pertusa coral reefs in mid-Norway in relation to seabed characteristics. J Mar Biol Assoc UK 81:581-597

Muscatine L, McCloskey LR, Marian RE (1981) Estimating the daily contribution of carbon from zooxanthellae to coral animal respiration. Limnol Oceanogr 26:601-611

> Peterson BJ, Fry B (1987) Stable isotopes in ecosystem studies. Annu Rev Ecol Syst 18:293-320

Rapp HT, Sneli JA (1999) Lophelia pertusa (L.) - myths and reality. 2nd Nord Mar Sci Meet, Hirtshals

Reitner J (2005) Calcifying extracellular mucus substances (EMS) of Madrepora oculata - a first geobiological approach. In: Freiwald A, Roberts JM (eds) Cold water corals and ecosystems. Springer-Verlag, Berlin, p 731-744

Roberts JM, Long D, Wilson JB, Mortensen PB, Gage JD (2003) The cold-water coral Lophelia pertusa (Scleractinia) and enigmatic seabed mounds along the north-east Atlantic margin: Are they related? Mar Pollut Bull 46: 7-20

Roberts JM, Wheeler AJ, Freiwald A (2006) Reefs of the deep: the biology and geology of cold-water coral ecosystems. Science 312:543-547

Rogers AD (1999) The biology of Lophelia pertusa (Linnaeus 1758). Int Rev Gesamten Hydrobiol 84:315-406

Rublee P, Lasker H, Gottfried M, Roman M (1980) Production and bacterial colonization of mucus from the soft coral Briarium asbestinum. Bull Mar Sci 30:888-893

Schuhmacher H (1977) Ability of fungiid corals to overcome sedimentation. In: Taylor DL (ed) Proceedings of the Third International Coral Reef Symposium, Vol 1. Biology. Rosensteil School of Marine and Atmospheric Science, Miami, FL, p 503-509

Tanaka Y, Miyajima T, Koike I, Hayashibara T, Ogawa H (2008) Production of dissolved and particulate organic matter by the reef-building corals Porites cylindrica and Acropora pulchra. Mar Pollut Bull 82(2):237-245

Thiem O, Ravagnan E, Fossa JH, Berntsen J (2006) Food supply mechanisms for cold water corals along a continental shelf edge. J Mar Syst 60:207-219

> van Duyl FC, Hegeman J, Hoogstratem A, Maier C (2008) Dissolved carbon fixation by sponge-microbe consortia of deep water coral mounds in the northeastern Atlantic Ocean. Mar Ecol Prog Ser 358:137-150 
van Soest RWM, Cleary D, de Kluijver MJ, Lavaleye MSS, Maier C, van Duyl FC (2007) Sponge diversity and community composition in Irish bathyal coral reefs. Contrib Zool 76:121-142

Weisz JB, Hentschel U, Lindquist N, Martens CS (2007) Linking abundance and diversity of sponge-associated microbial communities to metabolic differences in host sponges. Mar Biol 152:475-483

Wild C, Huettel M, Klueter A, Kremb SG, Rasheed M, Jørgensen BB (2004a) Coral mucus functions as an energy carrier and particle trap in the reef ecosystem. Nature 428:66-70

Wild C, Rasheed M, Werner U, Franke U, Johnstone R, Huettel M (2004b) Degradation and mineralization of coral

Editorial responsibility: Peter Edmunds,

Northridge, California, USA mucus in reef environments. Mar Ecol Prog Ser 267: 159-171

Wild C, Tollrian R, Huettel M (2004c) Rapid recycling of coral mass spawning products in permeable reef sediments. Mar Ecol Prog Ser 271:159-166

Wild C, Woyt H, Huettel M (2005) Influence of coral mucus release on nutrient fluxes in carbonate sands. Mar Ecol Prog Ser 287:87-98

Wild C, Jantzen C, Struck U, Hoegh-Guldberg O, Huettel M (2008) Biogeochemical responses following coral mass spawning on the Great Barrier Reef: pelagic-benthic coupling. Coral Reefs 27:123-132

Winkler LW (1888) The determination of dissolved oxygen in water. Ber Dtsch Chem Ges 21:2843-2857

Submitted: June 13, 2008; Accepted: September 2, 2008

Proofs received from author(s): December 2, 2008 